\title{
Respon Histopatologis Hepar Mencit (Mus musculus) yang Diinduksi Benzo(a)Piren terhadap Pemberian Taurin dan Ekstrak Daun Sirsak (Annona muricata)
}

\author{
Annisa Agata ${ }^{1,2)}$, Endang Linirin Widiastuti2 ${ }^{* *}$, G. Nugroho Susanto ${ }^{2)}$, dan Sutyarso ${ }^{2)}$ \\ ${ }^{1)}$ Fakultas Matematika dan Ilmu Pengetahuan Alam, Program Studi Magister Biologi, \\ Universitas Lampung, Bandar Lampung 35145 \\ ${ }^{2}$ Fakultas Matematika dan Ilmu Pengetahuan Alam, Jurusan Biologi, \\ Universitas Lampung, Bandar Lampung 35145
}

Diterima 24-06-2015 Disetujui 28-02-2016

\begin{abstract}
Cancer is a disease that is characterized by the existence of damage and cell abnormality in growth and differentiation. Liver cancer is a disorder of hepar tissue derivated from its tumors. Taurine is known as antioxidant but its role as anticancer needs to be explored more as well the role of Annona muricata leaf extract which is believed to have its role as anticancer substance. This research, therefore, aimed to explore the effect of taurine and Annona muricata leaf extract on the hepar histopathology of male mice (Mus musculus) induced by benzo( $\alpha$ )pyren in vivo. This research was carried out by using a complete randomized design, which consisted of 5 treatment groups which was repeated 5 times. Group I was given $0.2 \mathrm{~mL}$ corn oil for 15 days, group II was induced by benzo $(\alpha)$ pyren without taurin nor A. Muricata leaf extract for 10 days, group III was given $7.8 \mathrm{mg}$ taurine/BW/day (twice a day) starting from the $15^{\text {th }}$ days before the induction of benzo( $\alpha$ )pyren, group IV, after induced with benzo( $\alpha$ )pyren, taurine was given with dosage of $7.8 \mathrm{mg} / \mathrm{BW} /$ day, group V, after induced with benzo $(\alpha)$ pyren, soursop leaf extract was given with amount of $277.8 \mathrm{mg} / \mathrm{BW} / \mathrm{day}$. Data analyzed by Kruskal-Wallis test and one way ANOVA with Fisher test $(p>0.05)$. The results indicated that taurine had ability to recover the liver tissue induced by benzo $(\alpha)$ pyren as (carcinogenic) while, Annona muricata leaf extract had not shown any recover of tissue damage.
\end{abstract}

Keywords: benzo $(\alpha)$ phyren, hepar, leaf soursop (Annona muricata), taurine

\begin{abstract}
ABSTRAK
Kanker merupakan suatu penyakit yang ditandai dengan adanya kerusakan dan ketidaknormalan sel dalam mengatur pertumbuhan dan diferensiasinya. Kanker hati adalah gangguan pada hepar yang berawal dari tumor hepar. Taurin diketahui sebagai senyawa antioksidan, namun perannya dalam antikanker perlu dieksplorasi lebih jauh, demikian pula dengan ekstrak daun sirsak yang telah diminati oleh masyarakat sebagai bahan antikanker. Penelitian ini bertujuan untuk mengetahui peran senyawa taurin dan ekstrak daun sirsak terhadap gambaran histopatologi hepar mencit (Mus musculus) yang diinduksi benzo $(\alpha)$ piren secara in vivo. Penelitian ini dilaksanakan dengan menggunakan Rancangan Acak Lengkap (RAL) yang terdiri dari 5 kelompok perlakuan dengan masing-masing memiliki 5 ulangan, Kelompok I diberi 0,2 mL minyak jagung selama 15 hari, kelompok II diinduksi dengan benzo $(\alpha)$ piren tanpa pemberian bahan uji selama 10 hari, kelompok III pemberian taurin 7,8 mg/BB/hari (2 kali/hari) sejak 15 hari sebelum induksi benzo( $\alpha$ )piren), kelompok IV diinduksi benzo( $\alpha$ )piren dan dilanjutkan dengan pemberian taurin dosis $7,8 \mathrm{mg} / \mathrm{BB} / \mathrm{hari}$ ( $2 \mathrm{kali} / \mathrm{hari})$, kelompok V diinduksi benzo( $\alpha$ )piren, dilanjutkan pemberian daun sirsak dosis 277,8 mg/BB/hari. Data dianalisis dengan metode statistik menggunakan uji ANOVA satu arah
\end{abstract}

*Telp: +6282183035511
Email: elwidi@yahoo.com 
pada taraf 5\%. Data yang diperoleh dari pengamatan secara mikroskopis diuji dengan uji statistik Kruskal-Wallis. Hasil menunjukkan bahwa taurin memiliki kemampuan memperbaiki kerusakan jaringan hati yang diinduksi benzo( $\alpha)$ piren, sebaliknya tidak demikian dengan ekstrak daun sirsak.

Kata Kunci: benzo( $\alpha$ )piren, daun sirsak (Annona muricata), hepar, taurin

\section{PENDAHULUAN}

Kanker merupakan suatu jenis penyakit berupa pertumbuhan sel yang tidak terkendali secara normal. Neoplasma (tumor), terutama yang bersifat ganas (kanker), diketahui masih mempunyai mortalitas yang tinggi dan pengobatannya saat ini belum memuaskan. Mortalitas karena kanker di Indonesia menduduki urutan ke-6 (Sukardja 2000).

Kanker dapat disebabkan oleh faktor endogen maupun eksogen. Faktor endogen dapat berupa faktor genetik, penyakit, dan hormon. Sedangkan faktor eksogen dapat berasal dari makanan, virus, senyawa-senyawa karsinogenik seperti polusi udara, zat warna, logam-logam karsinogen, dan banyak penyebab lainnya seperti siklofosfamida (Hanahan \& Weinberg 2000).

Frekuensi kanker cenderung meninggi, disebabkan oleh perbaikan derajat kesehatan dan umur rata-rata harapan hidup yang meninggi sehingga makin banyak orang yang dapat mencapai usia yang lebih tua dan mudah terkena kanker (cancerous age), serta adanya peningkatan taraf pengetahuan tentang kebersihan sehingga kedudukan penyakit infeksi yang sebelumnya merupakan penyakit utama di Indonesia menjadi bergeser digantikan oleh penyakit kanker. Selain itu, peningkatan polutan meningkatkan paparan bahan karsinogenik sehingga dapat menambah frekuensi kanker (Uche \& Aprioku 2008).

Seiring dengan perkembangan industri di Indonesia mengakibatkan tingkat pencemaran lingkungan semakin meningkat. Salah satu bahan toksik yang dihasilkan akibat proses industri tersebut diantaranya benzo $(\alpha)$ piren. Merupakan suatu bahan karsinogen, yang mengandung inisiator maupun promoter, tetapi benzo( $\alpha$ )piren lebih aktif sebagai inisiator tumor (Sumpena 2009).

Salah satu organ yang penting dan vital untuk detoksifikasi bahan bersifat toksik yang masuk dalam tubuh adalah hepar. Hal ini menyebabkan hepar menjadi sering terpapar dengan zat-zat toksik atau zat karsinogenik yang mengakibatkan kerusakan sel hepar. Kerusakan sel hepar dapat berakibat proliferasi sel yang berlebihan sehingga terjadi tumor atau kanker hepar (King 2000).

Saat ini sedang dikembangkan berbagai pengobatan baru yang diambil dari alam. Salah satunya adalah pengembangan berbagai penelitian mengenai khasiat dari daun sirsak (Ma'at 2004). Zat aktif dalam daun sirsak yang mampu berperan sebagai antikanker adalah Annonaceous acetogenins Acetogenins merupakan inhibitor kuat dari kompleks I mitokondria atau $N A D H$ dehidrogenase. Zat ini akan mengakibatkan penurunan produksi ATP yang akan menyebabkan kematian sel kanker, lalu kemudian memicu terjadinya aktivasi jalur apoptosis serta mengaktifkan p53 yang dapat menghentikan siklus sel untuk mencegah terjadinya proliferasi tak terkendali. Selain itu, senyawa triterpenoid dan flavonoid di dalam daun sirsak juga memiliki efek antikarsinogenesis (Retnani 2011).

Taurin juga dapat berfungsi sebagai antikarsinogenik, manfaatnya sebagai antikarsinogenik yaitu pelindung selsel tubuh dari kerusakan yang disebabkan oleh radikal bebas. Taurin dianggap sebagai faktor penting untuk mengontrol berbagai perubahan biokimia yang terjadi selama proses penuaan dan membantu pembuangan radikal bebas (Ammer et al. 2013).

Dalam penelitian terkait, Schaffer et al. (2009), juga menemukan bahwa manfaat dari taurin dapat meningkatkan angiotensin II-dimediasi apoptosis yang dapat mencegah kanker.

Dengan infomasi tersebut, penelitian ini bertujuan untuk mengetahui pengaruh pemberian senyawa taurin dan ekstrak daun sirsak terhadap gambaran kerusakan histopatologi dan bobot hepar mencit (Mus musculus) yang diinduksi benzo $(\alpha)$ piren secara in vivo.

\section{BAHAN DAN METODE}

Penelitian dan pemeliharaan mencit ini dilakukan di Laboratorium Biologi Molekular dan Laboratorium MIPA 
Terpadu, Jurusan Biologi, Fakultas Matematika dan Ilmu Pengetahuan Alam, Universitas Lampung dan di Balai Penyidikan dan Pengujian Veteriner (BPPV) Regional III Bandar Lampung dari bulan Desember 2014 sampai Februari 2015. Bahan dan cara yang dipergunakan dalam pembuatan preparat histopatologi organ hati menggunakan standar pembuatan preparat dengan metode hematoksilin eosin (HE), derajat histopatologi hepar yang digunakan berdasarkan penelitian Uji Toksisitas Akut dan Subakut yang dilakukan Maretnowati et al. (2005) yaitu a) tingkat perubahan masih dalam keadaan normal memiliki skor 0 belum terjadi perubahan struktur histologi; b) tingkat perubahan kategori ringan (Mild) memiliki skor 1 dengan kerusakan kurang dari sepertiga dari seluruh lapang pandang; c) Tingkat perubahan kategori sedang (Moderate) memiliki skor 2 dengan kerusakan sepertiga hingga dua pertiga dari seluruh lapang pandang; d) Tingkat perubahan kategori berat (Severe) memiliki skor 3 dengan kerusakan lebih dari dua pertiga dari seluruh lapang pandang.

Penelitian ini dilaksanakan dengan menggunakan Rancangan Acak Lengkap (RAL) yang terdiri atas 5 kelompok perlakuan, Namun masing-masing perlakuan terdiri dari 5 ekor sebagai ulangan. Kelompok I diberi 0,2 mL minyak jagung selama 15 hari, kelompok II diinduksi dengan dosis benzo( $\alpha$ )piren $0,3 \mathrm{mg}$ dilarutkan dalam $0,2 \mathrm{~mL}$ minyak jagung tanpa pemberian bahan uji selama 10 hari dengan cara diinduksi atau disuntikan pada jaringan subkutan mencit di bagian tengkuk, kelompok III (taurine $7,8 \mathrm{mg} / \mathrm{BB} /$ hari (pagi dan sore sehingga total 15,6mg/BB/ hari dimulai sejak 15 hari sebelum induksi benzo $(\alpha)$ piren kelompok IV setelah diinduksi benzo $(\alpha)$ piren, taurin dosis $7,8 \mathrm{mg} / \mathrm{BB} /$ hari mencit (pagi dan sore), kelompok $\mathrm{V}$, setelah diinduksi benzo( $\alpha$ )piren)), diberi ekstrak daun sirsak dosis 277,8 mg/BB/hari (Tabel 1). Data selanjutnya dianalisis dengan uji Kruskal-Wallis dan one way ANOVA serta BNT pada taraf nyata $5 \%$.

\section{HASIL DAN PEMBAHASAN}

Hasil penelitian ini membuktikan bahwa taurin yang diberikan dapat mengurangi kerusakan yang terjadi pada sel hepar mencit yang diinjeksi benzo $(\alpha)$ piren. Dapat dibuktikan dengan melihat beberapa pengurangan kerusakan karsinogenesis yaitu nekrosa, kongesti, perdarahan pada sel hepatosit, lobus yang terinfeksi benzo $(\alpha)$ piren, degenerasi hidropik, degenerasi parenkim hingga degenerasi melemak. Hal tersebut terlihat pada berat badan mencit (Gambar 1), bobot hepar (Tabel 2) dan gambaran histopatologi (Gambar 2). Namun pada ekstrak daun sirsak yang diberikan belum menunjukkan adanya perbaikan kerusakan jaringan yang diinjeksi zat karsinogenik.

Berat Badan Mencit yang diinduksi Benzo( $\alpha$ )piren. Perubahan berat badan setelah diberi zat karsinogenik benzo $(\alpha)$ piren pada tubuh mencit secara statistik menggunakan uji ANOVA satu arah (one way ANOVA) pada taraf $5 \%(\mathrm{p}<0,05)$ tidak menunjukkan perbedaan yang signifikan (pada taraf $\alpha=5 \%$ ). Namun dari gambar histogram (Gambar 1) terlihat bahwa pemberian benzo $(\alpha)$ piren, ekstrak daun sirsak, dan taurin berpengaruh terhadap perubahan berat badan. Hal ini kemungkinan disebabkan taurin mampu memberikan kemampuan

Tabel 1 Dosis pada tiap kelompok perlakuan

\begin{tabular}{llc}
\hline \multicolumn{1}{c}{ Kelompok } & \multicolumn{1}{c}{ Keterangan } & Jumlah mencit \\
\hline I (kontrol normal) & $\begin{array}{l}\text { Diberi 0,2 mL minyak jagung dan selanjutnya hanya diberi akuades } \\
\text { sampai akhir masa penelitian }\end{array}$ & 5 \\
II (kontrol negatif) & $\begin{array}{l}\text { Diinduksi dengan benzo }(\alpha) \text { piren tanpa pemberian bahan uji selama 10 hari } \\
\text { dengan cara menyuntikkan larutan benzo }(\alpha) \text { piren pada jaringan subkutan } \\
\text { mencit di bagian tengkuk }\end{array}$ & 5 \\
III (preventif) & $\begin{array}{l}\text { Diberi taurin dengan 7,8 mg/BB/hari (pagi\&sore = 15,6 mg/BB/hari) } \\
\text { dimulai sejak 15 hari sebelum induksi benzo( } \alpha \text { )piren. }\end{array}$ & 5 \\
IV & $\begin{array}{l}\text { Setelah diinduksi benzo( } \alpha \text { ) piren, dilanjutkan pemberian senyawa taurin } \\
\text { dengan dosis 7,8 mg/BB/hari)(pagi\&sore = 15,6 mg/BB/hari). Pemberian }\end{array}$ & 5 \\
& zat uji taurin diberikan setiap hari secara oral selama 15 hari \\
V & $\begin{array}{l}\text { Setelah diinduksi benzo }(\alpha) \text { piren, dilanjutkan pemberian seduhan daun } \\
\text { sirsak dengan dosis 277,8 mg/BB. Pemberian ekstrak daun sirsak } \\
\text { diberikan setiap hari secara oral selama 15 hari }\end{array}$ & 5 \\
\hline
\end{tabular}




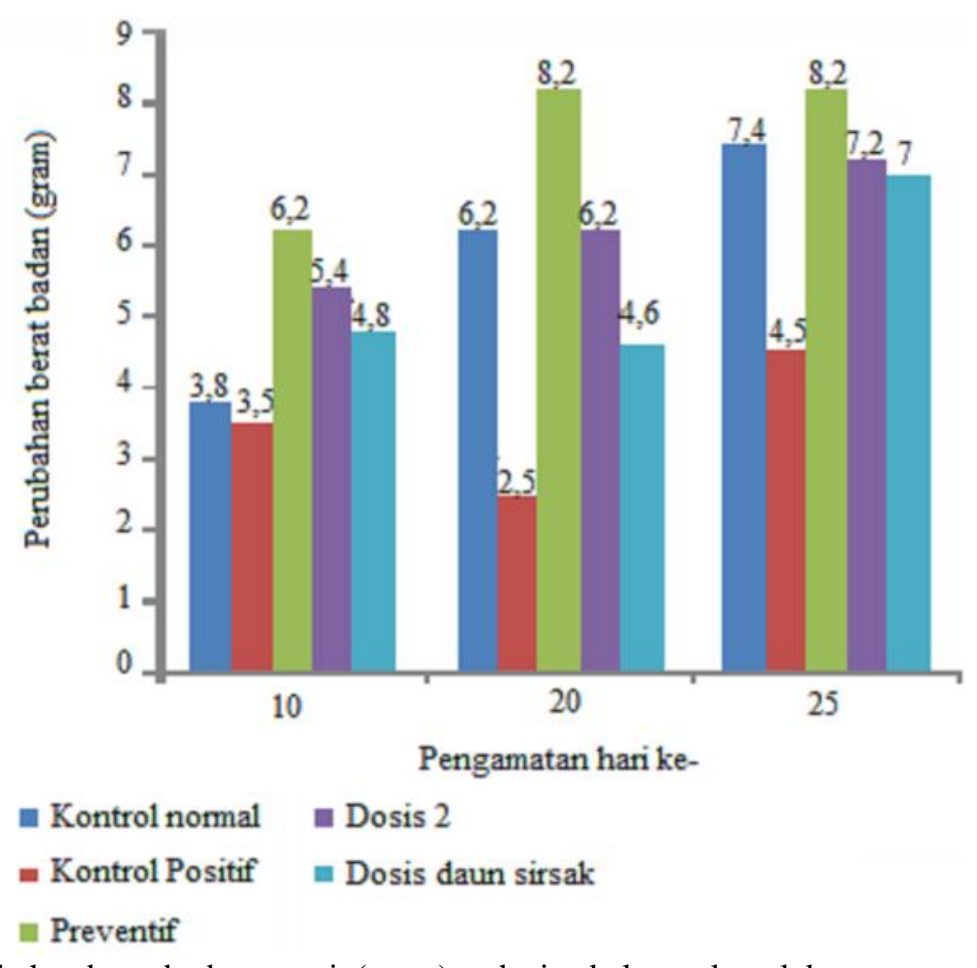

Gambar 1 Histogram perubahan berat badan mencit (gram) pada tiap kelompok perlakuan

Tabel 2 Pengaruh pemberian taurin dan ekstrak daun sirsak terhadap bobot hepar mencit yang diinduksi benzo $(\alpha)$ piren

\begin{tabular}{cc}
\hline Kelompok perlakuan & $\begin{array}{c}\text { Berat basah hepar mencit } \\
(\mathrm{X} \pm \mathrm{SD}) \text { gram }\end{array}$ \\
\hline KI & $2,4920 \pm 0,2839^{\mathrm{a}}$ \\
K2 & $1,5975 \pm 0,1372^{\mathrm{c}}$ \\
K3 & $2,0340 \pm 0,4318^{\mathrm{b}}$ \\
K4 & $2,0560 \pm 0,1394^{\mathrm{b}}$ \\
K5 & $1,8767 \pm 0,0379^{\mathrm{bc}}$ \\
\hline
\end{tabular}

Keterangan: Bobot hepar mencit (gram) $=\mathrm{v} \pm$ SD Angka yang diikuti dengan huruf yang sama pada kolom yang sama tidak berbeda nyata pada taraf 5\%.

regenerasi sel hepatosit yang cepat sehingga sel hepatosit yang rusak akibat efek zat karsinogenik dapat segera diperbaiki atau diganti dengan sel yang baru sehingga proses metabolisme yang dilakukan oleh hepar tetap berjalan normal (Niendya et al. 2011).

Pada perlakuan kontrol positif (yang hanya diberi benzo $(\alpha)$ piren) menunjukkan adanya penurunan berat badan pada hari ke 20 . Pemberian benzo $(\alpha)$ piren yang diinjeksi ke tubuh mencit akan mempengaruhi nafsu makan. Menurut Katz (2002), zat karsinogenik benzo( $\alpha$ )piren dapat peningkatan radikal bebas di dalam tubuh sehingga terjadi kerusakan pada organ hepar. Kerusakan yang ditimbulkan benzo $(\alpha)$ piren akan menyebabkan gangguan terhadap proses metabolisme. Terganggunya metabolisme berdampak pada kerja hipotalamus sebagai pusat regulasi pakan, akibatnya konsumsi pakan akan terganggu. Hal ini lah yang menyebabkan nafsu makan menurun yang berakibat menurunnya berat badan.

Khasiat kandungan ekstrak daun sirsak ini sangat bermanfaat, ini terlihat dari Gambar 1 pada hari ke-25 mengalami kenaikan berat badan setelah terjadi penurunan. Dalam daun sirsak terdapat senyawa Acetogenin. Acetogenin merupakan kumpulan senyawa aktif yang berada hampir pada setiap bagian tanaman sirsak (Li et al. 2008).

Dari penelitian acetogenin yang terkandung di dalam daun sirsak bisa digunakan untuk menghantam kanker usus, pankreas, ovarium, usus besar, payudara, liver, dan serviks, Annonaceous acetogenin bekerja dengan menghambat produksi ATP dengan mengganggu komplek satu mitokondria (Prasetya \& Laksono 2013).

Sel kanker membutuhkan banyak energi sehingga membutuhkan banyak ATP, acetogenin masuk dan menempel pada reseptor dinding sel dan merusak ATP pada dinding mitokondria. Dampaknya produksi energi di dalam sel kanker pun berhenti dan akhirnya sel kanker mati. 


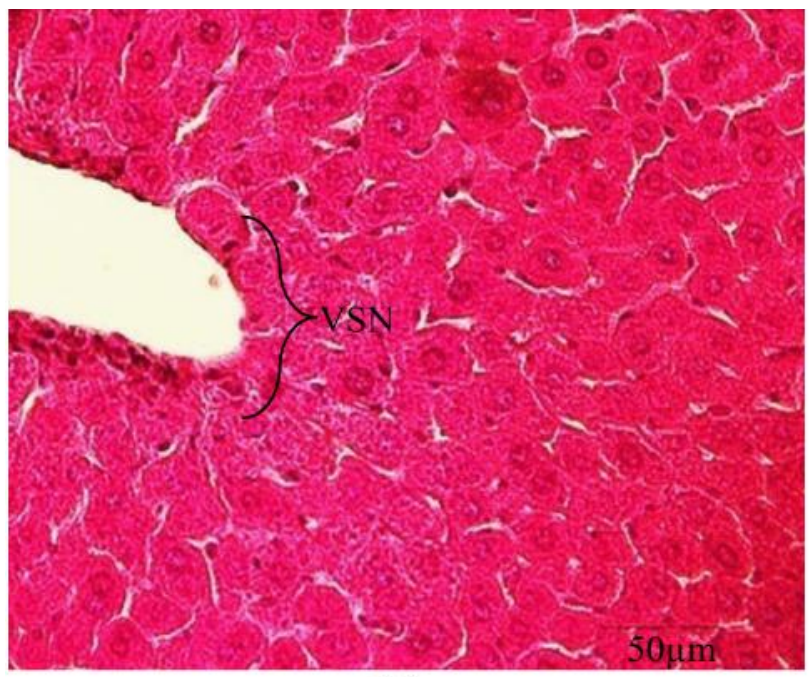

(a)

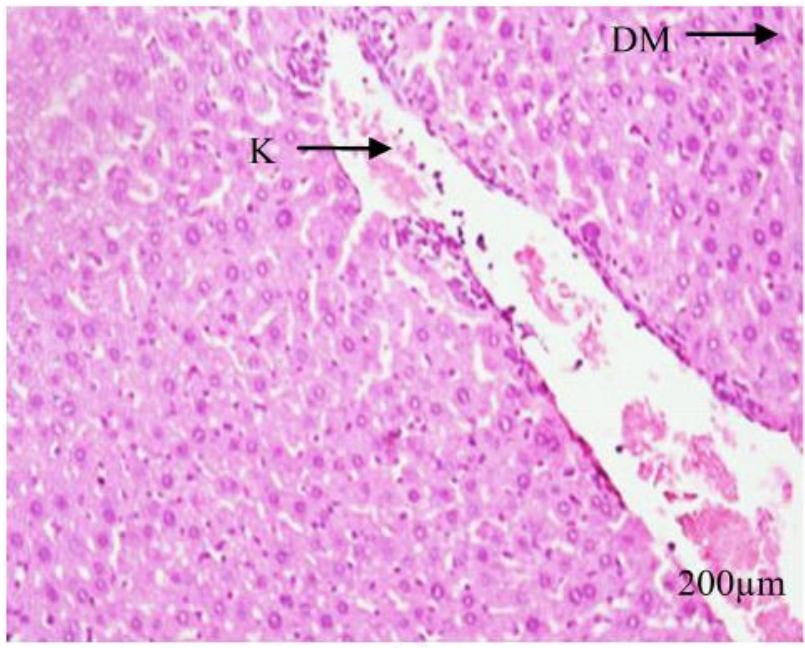

(c)

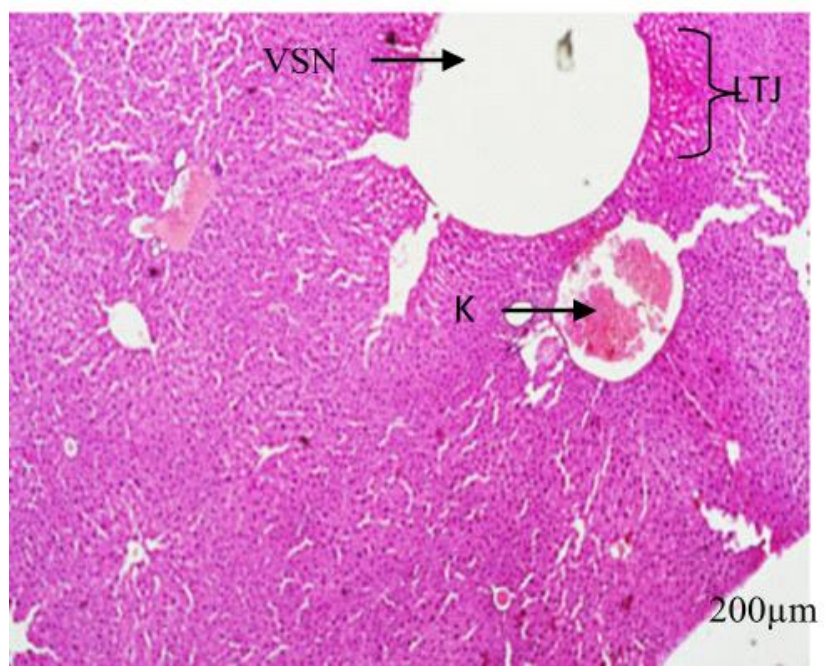

(e)

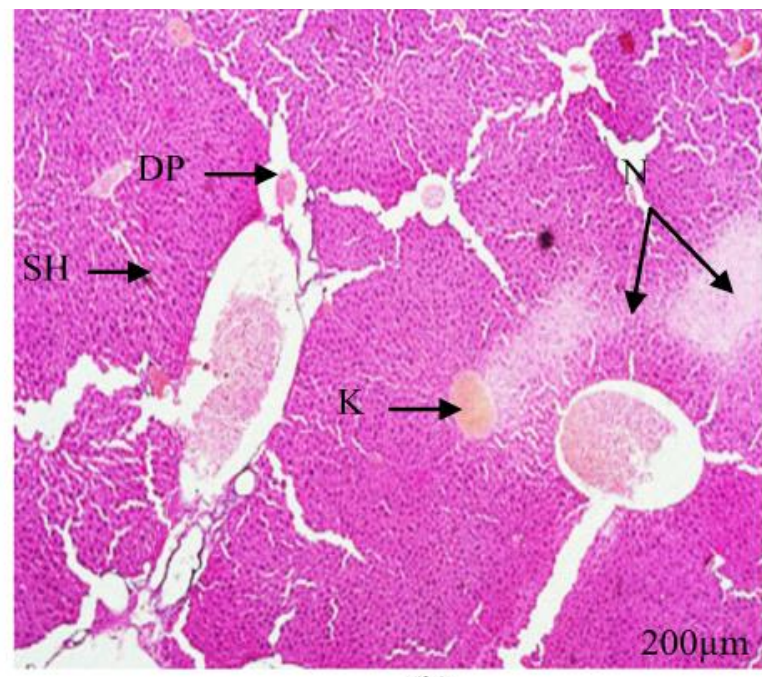

(b)

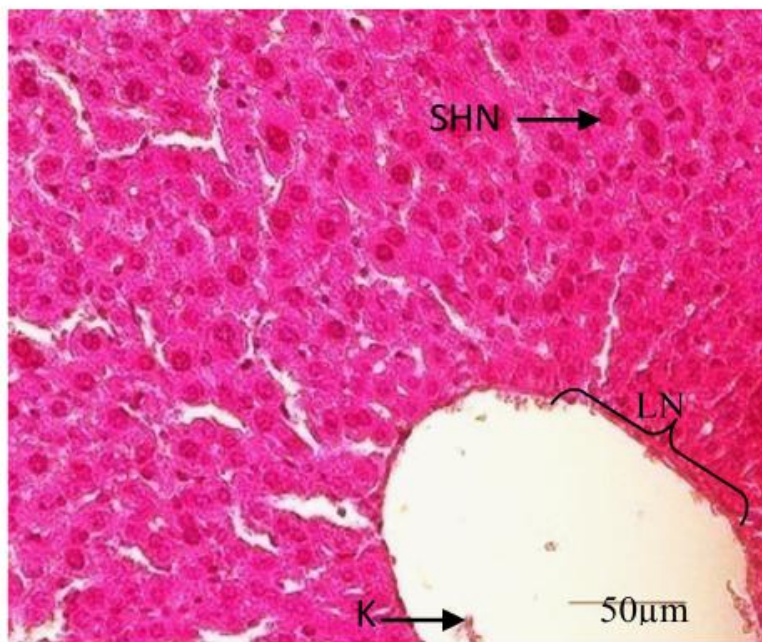

(d)

\section{Keterangan:}

a : histologis hepar mencit kelompok kontrol normal

b : histologis hepar mencit kelompok kontrol positif (benzo $(\alpha)$ piren)

c : histologis hepar mencit kelompok preventif

d : histologis hepar mencit kelompok taurin dosis 2 $(15,6 \mathrm{mg} / \mathrm{bb}$ mencit/hari)

e : histologis hepar mencit kelompok taurin dosis daun sirsak (277,8 mg/bb mencit/hari)

$\mathrm{N}$ : nekrosis; SR : sel radang; DP: degenerasi parenkim; $\mathrm{K}$ : kongesti; VSN: vena sentralis normal; DH :degenerasi hidropik; P: perdarahan; SH: sel hepatosit; DM : degenerasi melemak.

Gambar 2 Struktur histologis hati tiap kelompok perlakuan (Perbesaran 100x dan 400x) (pewarnaan hematoxylin-eosin) 
Hebatnya, acetogenin sangat selektif dan hanya menyerang sel kanker yang memiliki kelebihan ATP saja sehingga tidak merusak sel normal (Muliyah 2013). Perubahan berat badan setelah diberi zat karsinogenik benzo( $\alpha)$ piren pada tubuh mencit secara statistik tidak menunjukkan perbedaan yang signifikan (pada taraf $\alpha=$ $5 \%)$.

\section{Bobot Hepar Mencit yang diinduksi Benzo(a)piren.}

Pemberian taurin dan ekstrak daun sirsak berpengaruh terhadap bobot hepar dari kelompok yang diberi benzo( $\alpha$ )piren (Tabel 2). Namun pada kelompok perlakuan pemberian ekstrak daun sirsak yang menggunakan uji ANOVA satu arah (one way ANOVA) tidak menunjukkan perbedaan yang signifikan dengan kelompok kontrol positif (diinduksi benzo( $\alpha)$ piren).

$\operatorname{Benzo}(\alpha)$ piren senyawa radikal bebas yang banyak terdapat pada asap rokok, pembakaran yang tidak sempurna dan juga asap dapur rumah tangga yang sering dijumpai. Semakin tinggi paparan radikal bebas maka semakin tinggi pula kerusakan yang terjadi di organ, salah satunya akan terjadi di organ hati. Maka dari itu, zat karsinogenik akan dimetabolisme di hati dan akan menjadi senyawa yang reaktif setelah mengalami metabolisme, hal ini memungkinkan dapat menyebabkan kerusakan hati (Sumpena 2009).

Flavonoid yang terdapat di daun sirsak merupakan antioksidan yang kuat. Antioksidan akan menyebabkan terjadinya penghambatan radikal bebas dengan cara menetralkan radikal bebas sehingga mencegah kerusakan oksidatif pada sebagian besar biomolekul dan menghasilkan proteksi terhadap kerusakan oksidatif secara signifikan (Sreelatha \& Padma 2009). Antioksidan juga akan menstabilkan radikal bebas dengan melengkapi kekurangan elektron yang dimiliki radikal bebas, dan menghambat terjadinya reaksi berantai dari pembentukan radikal bebas yang dapat menimbulkan stres oksidatif sehingga pembentukan radikal bebas dapat ditekan atau dihambat (Waji \& Sugrami 2009).

Analisis Mikroskopis Kerusakan Hepar. Data yang diperoleh dari pengamatan secara mikroskopis diuji dengan menggunakan uji statistik Kruskal-Wallis yaitu untuk mengetahui adanya perbedaan dalam seluruh kelompok populasi. Hasil yang diperoleh dapat dilihat pada Tabel 3 bahwa pada kelompok kontrol positif yang diinduksi benzo( $\alpha$ )piren sel hepatosit normal jumlahnya mengalami penurunan atau mengalami kerusakan pada sel hepatosit, sinusoid tampak melebar serta tampak peningkatan jumlah sel-sel yang mengalami degenerasi dan nekrosis yaitu sebesar 26-50\%. Hal ini terjadi karena akumulasi lemak di dalam sel hati yang biasanya ditandai dengan adanya vakuola-vakuola kecil di dalam sitoplasma. Vakuola-vakuola ini dapat membesar dan mendesak inti sel ke bagian tepi sel hati. Apabila sel hati mengalami kerusakan oleh berbagai sebab, maka serangkaian perubahan morfologi dapat dijumpai pada hati (Niendya et al. 2011).

Namun pada kelompok preventif, kelompok dosis 2, dan kelompok daun sirsak jumlah sel normal mengalami peningkatan kembali. Pada kelompok dosis 2 dan preventif terlihat kerusakan pada hepar mulai menurun seperti pada kerusakan nekrosa, bendung darah (kongesti), perdarahan,

Tabel 3 Hasil Analisis data kerusakan hepar dengan menggunakan uji Kruskal-Wallis(derajat kerusakan hepar)

\begin{tabular}{llllllllll}
\hline Ulangan & $\mathrm{N}$ & $\mathrm{K}$ & $\mathrm{P}$ & $\mathrm{SR}$ & $\mathrm{L}$ & $\mathrm{SH}$ & $\mathrm{DH}$ & $\mathrm{DP}$ & $\mathrm{DM}$ \\
\hline $\mathrm{K} 1$ & 0,00 & 1,00 & 0,00 & 0,00 & 0,00 & 0,00 & 0,00 & 0,00 & 0,00 \\
$\mathrm{~K} 2$ & 1,00 & 2,00 & 2,00 & 2,00 & 2,00 & 2,00 & 1,500 & 0,00 & 1,00 \\
K3 & 1,00 & 1,00 & 1,00 & 0,00 & 0,00 & 0,00 & 0,00 & 0,00 & 0,00 \\
K4 & 1,00 & 1,00 & 1,00 & 1,00 & 0,00 & 0,00 & 0,00 & 0,00 & 0,00 \\
K5 & 0,00 & 2,00 & 1,00 & 1,00 & 0,00 & 1,00 & 1,00 & 0,00 & 1,00 \\
\hline
\end{tabular}

Keterangan : Nilai adalah *median. $\alpha=0,05$

\begin{tabular}{|c|c|c|c|}
\hline $\mathrm{N}$ & : Nekrosa & : Lobus yang terinfeksi benzo $(\alpha)$ piren & DP : Degenerasi Parenkim \\
\hline K & : Kongesti & : Perdarahan pada Sel Hepatosit & : Degenerasi Melemak \\
\hline $\mathrm{P}$ & : Perdarahan & : Degenerasi Hidropik & \\
\hline SR & : Sel Radang & & \\
\hline
\end{tabular}

(*) Skor derajat kerusakan dapat dilihat pada Tabel 4 
sel radang, lobus, sel hepatosit, degenerasi (hidropik, parenkim, melemak). Namun pada dosis daun sirsak sedikit mengalami kerusakan histologis nekrosa, kongesti, dan sel radang.

Radang merupakan respon fisiologi lokal terhadap cedera jaringan. Infiltrasi sel radang limfosit pada vena sentralis disebabkan karena rusaknya sel endotel yang sangat peka terhadap zat racun, peradangan pada hepar dimulai pada vena sentralis sebagai tempat penampungan darah yang berasal dari arteri hepatika dan vena porta. Akibat pembendungan ini sirkulasi darah terganggu dan dapat mengakibatkan sel hepar mengalami degenerasi hingga nekrosis karena kekurangan natrium dan oksigen (Greaves et al. 2000).

Selain radang, hasil pemeriksaan histopatologis menunjukkan adanya degenerasi melemak (fatty degeneration) yaitu merupakan akumulasi lemak dalam sitoplasma sel. Biasanya terjadi dalam sel-sel parenkimatosa, seperti sel hepar. Pada pewarnaan hematoksilin eosin (HE), lemak yang hilang akibat proses dehidrasi dengan alkohol akan terbentuk vakuola-vakuola sehingga sering disebut degenerasi vakuola. Lemak dalam sitoplasma sel dapat mendesak inti sel ke pinggir yang tampak pada pemeriksaan mikroskopik. Penyebabnya antara lain gangguan hepatosit (diet, toksik) sehingga terbentuk lipoprotein (Akhila et al. 2007).

Hepatosit yang mengalami piknosis tampak menghitam, namun masih memiliki membran sel. Nukleus belum tampak terfragmentasi. Beberapa sel yang mengalami piknosis tampak lebih besar daripada hepatosit normal, namun ada juga yang mempunyai ukuran lebih kecil dari hepatosit normal, Hepatosit berbentuk bulat dengan kondisi sel yang masih tersusun secara radier (Fajariah $e t$ al.2010).

Hal ini sesuai dengan pernyataan Ngabekti \& Isnaeni (2000), piknosis atau pengerutan inti merupakan homogenisasi sitoplasma. Hepatosit yang mengalami piknosis ini tampak lebih gelap daripada hepatosit normal. Selain itu, hepatosit tampak semakin kecil dan mengkerut sehingga mempunyai bentuk yang tidak teratur.

Histologis Hepar Mencit yang diinduksi

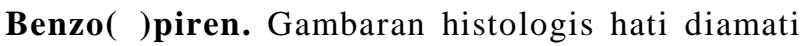
menggunakan mikroskop cahaya. Setelah dilakukan pengamatan terhadap gambaran histopatologi hepar mencit pada penelitian yang telah dilakukan, didapatkan hasil bahwa pada kelompok kontrol normal (Gambar 2.a) tidak menunjukkan adanya kerusakan nekrosis, kongesti, perdarahan, sel radang, regenerasi parenkim, degenerasi hidropik, dan degenerasi melemak. Hal ini disebabkan kelompok kontrol hanya diberikan minyak jagung dan pakan standar serta tidak diinduksi benzo $(\alpha)$ piren gambaran hepatositnya normal. Keadaan histologi hati pada kelompok tersebut menunjukkan gambaran hepatosit normal yang tersusun radial pada lobulus hati. Menurut Lu (1994), hepatosit adalah jenis sel yang menyusun sebagian besar organ hepar. Hepatosit bertanggung jawab terhadap peran sentral hepar dalam metabolisme. Menurut Syahrizal (2008), apabila sel hepar mengalami kerusakan yang disebabkan oleh berbagai faktor, maka akan terjadi serangkaian perubahan morfologi pada sel hepar. Perubahan tersebut dapat bersifat subletal yaitu degeneratif atau pun letal berupa nekrotik.

Vena sentralis merupakan pembuluh darah yang terletak di bagian tengah lobulus. Keadaan tersebut menunjukkan bahwa histologi hati kontrol normal (Gambar 2a). Struktur histopatologis kelompok kontrol positif (Gambar 2b) terdapat vena sentralis yang mengalami pembendungan darah (kongesti). Pembendungan tersebut ditandai oleh adanya massa yang berwarna merah yang menutupi lumen vena sentralis (Greaves 2000).

Pada hasil pengamatan perubahan struktur histologis hepatosit diketahui bahwa pada kelompok kontrol positif ditemukan adanya perubahan sel berupa degenerasi parenkimatosa, degenerasi hidropik, dan nekrosis (Gambar 2b). Perubahan degenerasi adalah perubahan yang prosesnya bersifat reversibel yaitu dapat kembali seperti semula, artinya jika rangsangan yang menyebabkan kerusakan sel dihentikan, maka sel akan kembali sehat seperti saat sebelum diberi rangsangan. Sebaliknya, nekrosis adalah perubahan yang prosesnya bersifat irreversibel. Sel yang mengalami nekrosis tidak dapat lagi kembali seperti semula. Pada titik akhir nekrosis, sel akan mengalami kematian (Baroroh \& Warsinah 2009).

Secara teoritis, proses kerusakan sel hepar dimulai dari proses degenerasi dengan ciri pembengkakan sel. Ciri tersebut teramati pada perlakuan benzo $(\alpha)$ piren (Gambar 2a). Perlakuan benzo( $\alpha$ )piren tampaknya menyebabkan cairan ekstrasel memasuki sitosol dalam jumlah besar. 
Menurut Hariyatmi (2004), salah satu perubahan yang diinduksi oleh radikal bebas yaitu perubahan sifat-sifat membran sel dan membran sitoplasmik pada unsur-unsur sel seperti mitokondria dan lisosom yang diakibatkan oleh lemak peroksida. Setelah merusak membran sel, efek toksikan dapat juga mencapai inti dan merusaknya, yang mengakibatkan struktur sel menjadi tidak normal dan lama kelamaan bermuara pada nekrosis. Menurut Baroroh \& Warsinah (2009), nekrosis ialah degradasi atau disorganisasi seluler yang irreversibel atau kematian sel jaringan tubuh sebagai akibat pengaruh jelas, dengan perubahan morfologi yang nyata pada inti sel sebagai piknosis, karyoreksis, dan karyolisis.

Menurut Syahrizal (2008), apabila senyawa racun yang masuk terlalu besar sehingga bersifat karsinogenik pada hepar, maka akan menimbulkan degenerasi jaringan hepar. Kemudian terjadi nekrosis yang dapat merusak jaringan hepar. Dengan demikian perlu hati-hati dan pertimbangan yang cermat agar terhindar dari bahaya zat karsinogenik yaitu benzo( $\alpha)$ piren. $\operatorname{Benzo}(\alpha)$ piren dalam darah dapat menyebabkan kerusakan berbagai organ termasuk organ hati. Hal ini diakibatkan oleh kemampuan benzo $(\alpha)$ piren untuk membentuk radikal bebas dalam tubuh serta menurunkan kemampuan antioksidan sehingga dengan sendirinya akan terjadi stres oksidatif. Selain itu dari berbagai penelitian diketahui bahwa benzo $(\alpha)$ piren secara langsung dapat menimbulkan terjadinya gangguan dalam proses biokimia normal sistem hepatobilier dan juga dapat menyebabkan nekrosis sel hati.

Pada Gambar $2 b$ terdapat hepatosit yang mengalami perlemakan (degenerasi melemak). Sel-sel tersebut terlihat sebagai vesikel-vesikel kosong yang tadinya berisi lemak, namun karena proses pembuatan dan pewarnaan preparat, lemak tersebut larut dalam alkohol, sehingga yang tersisa hanya vesikel-vesikel kosong (Klaassen 2001).

Temuan ini sesuai dengan pendapat Lu (1994), yang menyatakan bahwa hepar sering menjadi organ sasaran zat karsinogenik karena sebagian besar toksikan memasuki tubuh melalui sistem gastrointestinal dan setelah diserap karsinogenik dibawa vena porta ke hepar.

Kerusakan hepatosit karena pemberian benzo $(\alpha)$ piren secara terus-menerus selama 25 hari akan menimbulkan stress oksidatif yang menghasilkan hidrogen peroksida. Menurut Trisnowati (2009), hidrogen peroksida dapat beraksi dengan senyawa dalam tubuh dan membentuk radikal hidroksil yang sangat reaktif. Radikal hidroksil tersebut menyebabkan peroksidasi lipid. Peroksidasi lipid menyebabkan kerusakan membran sel dan kemudian mengakibatkan struktur sel menjadi tidak normal dan merusak fungsi sel.

Struktur histologis hati kelompok preventif dapat dilihat pada Gambar 2c. Keadaan histologis hati pada kelompok tersebut menunjukkan gambaran hepatosit yang hampir mendekati keadaan hepatosit normal pada kontrol normal, meskipun masih ditemukan adanya hepatosit normal yang mengalami pembendungan darah pada sinusoid-sinusoid dan sel radang. Pembendungan tersebut terlihat sebagai sel-sel darah berwarna merah terang yang mengisi sinusoid-sinusoid hati. Terdapat pula hepatosithepatosit dan vena sentralis yang menunjukkan kondisi normal berdasarkan perbandingan dengan kontrol normal.

Struktur histologis hati kelompok perlakuan dosis 2 dapat dilihat pada Gambar 2d. Berdasarkan gambaran kelompok dosis 2, hepatosit pada gambar tersebut menunjukkan morfologi hepatosit normal yang menyerupai keadaan hepatosit kontrol normal. Pada gambaran histologis kelompok dosis 2 hampir mendekati keadaan lobus dan ventra sentralis pada kelompok kontrol normal, meskipun masih ditemukan adanya gambaran yang mengalami pembendungan darah atau kongesti dan sel radang. Jika dibandingkan dengan kelompok kontrol positif yang mengalami pengrusakan cukup berat, gambaran histologis pada kelompok dosis 2 ini mengalami sedikit pengurangan kerusakan.

Pada kelompok perlakuan yang diberikan taurin dosis 2 dan kelompok preventif diperoleh data bahwa kerusakan struktur histologis menurun dibandingkan dengan kelompok kontrol positif (Gambar 2a). Menurut Hariyatmi (2004), taurin berfungsi sebagai antioksidan pemulung (scavenger) superoksida dan radikal bebas. Berdasarkan hasil yang diperoleh, tampaknya fungsi scavenger tersebut efektif memperbaiki kerusakan sel hepar akibat benzo $(\alpha)$ piren dengan efek pemulihan 1-25\% (Tabel 4). Menurut Smayda (2002), taurine sangat efektif sebagai antioksidan atau radikal bebas salah satunya kanker pada konsentrasi tinggi. Pemberian dosis tinggi pada taurin akan mengurangi lipid peroksida pada hepar. 
Tabel 4 Skor penilaian derajat kerusakan histopatologi hepar mencit yang diinduksi benzo( $\alpha)$ piren (Hansel \& Barnes 2004)

\begin{tabular}{llc}
\hline \multicolumn{1}{c}{ Tingkat perubahan } & \multicolumn{1}{c}{ Keterangan } & Skor \\
\hline Normal & Tidak terjadi perubahan struktur histologi & 0 \\
Mild (ringan) & Kerusakan kurang dari sepertiga dari seluruh lapang pandang & 1 \\
Moderate (sedang) & Kerusakan sepertiga hingga dua pertiga dari seluruh lapang pandang & 2 \\
Severe (berat) & Kerusakan lebih dari dua pertiga dari seluruh lapang pandang & 3 \\
\hline
\end{tabular}

Gambaran histologis hati kelompok 5 dapat dilihat pada Gambar 2e. Pada kelompok perlakuan yang diberikan daun sirsak diperoleh data bahwa kerusakan struktur histologis menurun dibandingkan dengan kelompok kontrol positif (Gambar 2a), namun secara statistik perbedaan tersebut tidak terlihat perbedaan yang nyata. Hal ini mungkin disebabkan oleh dosis daun sirsak yang diberikan belum efektif dalam memperbaiki hepar. Pada hasil pengamatan yang dapat dilihat pada kelompok ekstrak daun sirsak (Gambar 2e) terdapat hepatosit yang mengalami steatosis mikroveskular (degenerasi melemak) (Greaves \& Path 2000).

Selain itu terdapat pula vena sentralis yang mengalami pembendungan darah yang terlihat sebagai lumen vena sentralis yang tertutup oleh massa yang berwarna merah yang merupakan darah yang membendung pembuluh tersebut, dan juga terdapat perdarahan perifer dan sel radang di sekitar sel hepar. Pada kelompok dosis daun sirsak juga terdapat vena sentralis, sel hepatosit dan lobus yang mendekati keadaan normal seperti gambar histologi pada kontrol normal. Walaupun penurunan kerusakan belum mencapai gambaran histopatologi normal, dari hasil penelitian ini sudah mengalami perbaikan, Ini mungkin disebabkan oleh kurang waktu pemberian ekstrak daun sirsak ataupun kesalahan dalam pemberian dosis ekstrak daun sirsak.

Ekstrak daun sirsak memiliki kandungan senyawa acetogenin yang berfungsi sebagai antitumor. Pengaruh acetogeninmenjadikan permeabilitas membran terganggu dan menghambat berkembangnya sel kanker sehingga memberikan kesempatan bagi tubuh untuk melakukan mekanisme pengaturan kematian sel melalui apoptosis yang dipicu TNF $\alpha$, selain itu ekstrak daun sirsak memiliki kandungan flavonoid, terpenoid, alkaloid, minyak atsiri, polifenol, saponin, dan tanin yang berperan sebagai anti tumor, antimikroba, antiparasit, dan antivirus (Amelia et al. 2012).

Senyawa golongan flavonoid juga mampu menginduksi apoptosis dan menghentikan siklus sel melalui mekanisme inhibisi enzim topoisomerase. Selain itu flavonoid juga menghambat aktivitas karsinogen melalui inhibisi sitokrom P450 sehingga senyawa karsinogen menjadi tidak reaktif. Flavonoid juga meningkatkan ekspresi enzim gluthation $S$-transferase yang dapat mendetoksifikasi karsinogen sehingga cepat dieliminasi tubuh (Ren et al. 2003).

\section{SIMPULAN}

Pemberian senyawa taurin berpengaruh protektif dan terapeutik terhadap struktur kerusakan histopatologi dan bobot hepar mencit yang diinduksi zat karsinogenik benzo( $\alpha)$ piren, sebaliknya ekstrak daun sirsak belum menunjukkan adanya perbaikan kerusakan jaringan hepar.

\section{UCAPAN TERIMAKASIH}

Penulis mengucapkan Terima Kasih kepada kepala Lab Molekuler Ibu Endang Linirin Widiastuti, Ph.D, dan kepala Lab Patologi Balai Penyidikan dan Pengujian Veteriner (BPPV) Regional III Bandar Lampung dan seluruh pihak yang telah membantu penulis dalam menyelesaikan artikel ini.

\section{DAFTAR PUSTAKA}

Akhila, J,S., Shyamjith, Deepa \& Alwar, M.C. 2007. Acute toxicity studies and determination of median lethal dose. Curr Sci 93(7): 917-920.

Amelia, F,E., Angeline, K \& Wahyu. 2012. Tablet salut enteric ekstrak etanol daun sirsak (Annona muricata) sebagai antikanker kolon yang potensial. Skripsi Sarjana. Yogyakarta: Universitas Gadjah Mada. 
Ammer, E,M., Shaaban, A.A., Ghonem, H.A \& Elkashef, H.A. 2013. Effect of Taurine on The Respiratory System of Rats. J Food Pharm Sci 1(2): 2229.

Baroroh, H.N \& Warsinah. 2009. Antiinflammatory activity of ethanolic extract of leaves of jarak pagar (Jatropa curcas L.) and neutrophils profile in rats foot induced Carrageenan. Proceedings of International Conference On Medicinal Plants. Surabaya, 22-23.

Fajariyah, S., Utami, E.T \& Arisandi, Y. 2010. Efek pemberian estrogen sintetis (Diethylstillbestrol) terhadap struktur hepar dan kadar SGOT dan SGPT pada mencit (Mus musculus) betina strain Balb/C. $J$ Ilmu dasar 11(1): 76-82.

Greaves, M.B.P., Ch, B \& Path, F.R.C. 2000. Histopathology of Preclinical Toxicity Studies. Amsterdam: Elsevier.

Hanahan, D \& Weinberg, R.A. 2000. The hallmarks of cancer. Cell 100(2): 57-70.

Hariyatmi. 2004. Kemampuan Vitamin E sebagai Antioksidan terhadap Radikal Bebas pada Usia Lanjut. MIPA 14(1): 52-60.

Katz, B.G. 2002. Basic and clinical pharmacology, alih bahasa : Dripa Sjabana, Endang Isbianti, Achmad Basori, Moch, Sudjak N, Indriyatni, Ramadhani RB, Sunarni Zakaria, Salemba Medika, Surabaya.

King, R.J.B. 2000. Cancer Biology, 2nd ed,. Pearson Education Limited. London.

Klaassen, C.D. (ed). 2001. Casarett and Doull's Toxicology. The Science of Poison. McGraw Hill. New York.

Li, N., Shi, Z., Tang, Y., Chen, J \& Li, X. 2008. Recent progress on the total synthesis of acetogenins from Annonaceae. Beilstein Journal of Organic Chemistry 4(48): 4-12.

Ma'at, S. 2004. Obat tradisional untuk pelayanan kesehatan formal. Prosiding Seminar Nasional. Surabaya. 5 September 2004.

Niendya, W.A., Muhammad, A.D \& Teguh, S. 2011. Rasio Hepar Bobot-Tubuh Mencit (Mus musculus) setelah Pemberian Diazepam, Formalin, dan Minuman Beralkohol. Buletin Anatomi dan Fisiologi XI(1) Maret 2011.

Ngabekti, S \& Isnaeni, W. 2000. Pemanfaatan Kurkumin Untuk Mengeliminir Pengaruh Diazonin terhadap Kerusakan Hati Mencit (Mus musculus L). Semarang: Fakultas MIPA Universitas Negeri Semarang.
Prasetya, G \& Laksono, H. 2013. Ekstrak daun sirsak (Annona muricata) menggunakan pelarut etanol. Jurnal Tekonologi Kimia Industri 1(2): 111-115.

Ren, W., Qiao, Z., Wang, H., Zhu, L \& Zhang, L. 2003. Flavonoids: promising anticancer agent. Medicinal Research Review 23(4): 519-534.

Retnani, V. 2011. Pengaruh suplementasi ekstrak daun Annona muricata terhadap kejadian displasia epitel kelenjar payudara tikus sprague dawley yang diinduksi 7,12-dimetilbenz(Q)antrasena (DMBA). Skripsi Sarjana. Semarang: Fakultas Kedokteran Universitas Diponegoro.

Smayda, R. 2002. Contemporary review of therapeutic benefits of the amino acid taurin. The Journal of Biological Chemistry 257(6): 2802-2805.

Schaffer, S., Ramila, K.C., Jong, C.J., Ito, T \& Azuma, J. 2009. Role of protein phosphorylation in Tau TKO cardiomyopathy, Int Taurine Symp.

Sukardja, IDE. 2000. Onkologi Klinik edisi 2. Surabaya: Airlangga University Press.

Sreelatha, S \& Padma, P.R. 2009. Antioxidant activity and total phenolic content of Moringa oleifera leaves in two stages of maturity. Plant foods hum nutr 64(4): 302-311.

Sumpena \& Yana. 2009. Uji Mutagenisitas Benzo (alfa) piren dengan Metode Mikronukleus pada Sumsum Tulang Mencit Albino (Mus musculus). Cermin Dunia Kedokteran 36(1): 33-36.

Syahrizal, D. 2008. Pengaruh Proteksi Vitamin C terhadap Enzim Transaminase dan Gambaran Histopatologis hati Mencit yang Dipapar Plumbum. Tesis Pasca Sarjana. Medan: Fakultas Kedokteran. Universitas Sumatera Utara.

Uche, F.I \& Aprioku, J.S. 2008. The phytochemical constituents, analgesic and antiinflammatory effects of methanol extract of jatropha curcas leaves in mice and wister albino rats. J Appl Sci Environ Manage 12(4): 99-102.

Waji, R,A \& Sugrami, A. 2009. Makalah kimia organik bahan alam flavonoid (quercetin). Makassar: Universitas Hasanuddin 8-9. 